\title{
Globe
}

Revue internationale d'études québécoises

\section{Discours sur la ville québécoise}

Volume 5, numéro 1, 2002

Le dit et le non-dit de Montréal

URI : https://id.erudit.org/iderudit/1000660ar

DOI : https://doi.org/10.7202/1000660ar

Aller au sommaire du numéro

Éditeur(s)

Globe, Revue internationale d'études québécoises

ISSN

1481-5869 (imprimé)

1923-8231 (numérique)

Découvrir la revue

Citer ce document

(2002). Discours sur la ville québécoise. Globe, 5(1), 11-11.

https://doi.org/10.7202/1000660ar d'utilisation que vous pouvez consulter en ligne.

https://apropos.erudit.org/fr/usagers/politique-dutilisation/ 


\section{Présentation}

\section{Discours sur la ville québécoise}

À la suite des travaux réalisés dans le cadre du $350^{\circ}$ anniversaire de la ville par l'équipe de "Montréal imaginaire ", sous la direction de Pierre Nepveu et de Gilles Marcotte, Marie Cusson propose aujourd'hui un numéro sur l'entre-choc des récits tel qu'il peut être analysé dans les discours littéraires, cinématographiques et architecturaux.

Dans son introduction, elle relève que l'analyse du langage permet de définir la ville comme "un cadre épistémologique interprétatif "qui révèle la dynamique des identités. En ouverture, le texte de Pierre Ouellet analyse l'ethos urbain comme une "manière d'être dans le discours", alors que Hubert Beringer se penche sur le discours méconnu qui entoure l'audacieux projet architectural d'Habitat 67. Pour leur part, Mark Lajoie et Kathryn Allen découvrent, à travers l'œeuvre de William Weintraub, les éléments d'un discours social commun à la minorité anglomontréalaise. Suivent les articles de Bill Marshall, qui compare les éléments urbains des films Louis 19, le roi des ondes et EdTV, celui de Marie Cusson, sur la nouvelle "Les aurores montréales " de Monique Proulx, et enfin celui de Pierre J. Ouellet, sur les questions du temps et de l'espace chez les poètes Clément Marchand et Claude Beausoleil,

Le numéro se termine sur deux études libres : une exploration du traitement de l'influence amérindienne dans l'historiographie et une relecture du régionalisme littéraire du début du siècle. Suivent le habituelles recensions et la bibliographie attendue des parutions récentes en études québécoises. 